\title{
Editorial
}

\section{THE INJUSTICE OF THE LAW}

The dispensing of injustice is always in the right hands

- Stanislaus Lec. Polish writer and anti-fascist militant.

Elvira Arellano - the Mexican immigrant mother of a US-born son who has fought both to focus the attention of US society and force the US government to address the plight of millions of undocumented immigrants in this country and around the world, who live with the threat of deportation and separation from their families - was arrested on August 19, 2007.

It is a sobering moment for this country, and indeed for all human beings all over the world, who care about the defense of justice, of human rights and dignity. Having been ordered to leave the United States and, in so doing either to abandon her child, or take him, a US citizen, to grow up in a country not his own, Arellano chose on August 15, 2006, to avoid deportation by taking refuge in Chicago's Adalberto United Methodist Church, thus launching the beginning of a new sanctuary movement in the United States. As she explained: "I only have two choices. I either go to my country, Mexico, or stay and keep fighting. I decided to stay and fight."

Her arrest raises again the difficulty of actually defining her "crime" and pinpointing its implications for US society. How did she actually wrong this country? Was her decision to try to give her US-born son, a better life and education than she could in Mexico, sufficient cause for her to be arrested? Is she a threat to this society that for years has loudly claimed to defend "our family values"?

Did Elvira ruin this country? Did any American die because of her? Did any US citizen suffer as a result of her decision to stay and raise her US-born son in the United States? Since when is it considered a crime in the United States to want the best for one's child? Yes, it is true that there are "immigration laws" that dictate that she, like the 12 million other undocumented immigrants should not have trespassed into the United States. But what about the lack of laws aimed at creating conditions in Mexico to prevent this ongoing human movement across the border? After more than a decade, it is now patently clear to all that the North American Free Trade Agreement (NAFTA) has created unbearable conditions in Mexico that are forcing millions to leave their homes, as Elvira did, in search of survival and a better life for their children. It is worthwhile to remember that NAFTA was signed by the governments of the United States, Mexico and Canada, over the considerable opposition waged by citizens and organizations in all three countries, and went into effect on January 1, 1994,

. Latino Studies 2007, 5, (285-287) (c) 2007 Palgrave Macmillan Ltd 1476-3435/07 \$30.00 www.palgrave-journals.com/lst 
which not coincidentally, sparked the current and unprecedented increase in Mexican immigration to the United States.

The lack of political will and resolve in the US Congress to address and solve the immigration problem for the millions of people who are living in the shadows of our society was patently clear earlier this summer. The same people who are being kept in the shadows are simultaneously and blatantly being used in every aspect of the US economy, whether in businesses, farms, factories, private homes and backyards, restaurants, cleaning companies, transportation and other industries, in order to ensure that the quality of life in this society remains both high and affordable for all Americans. Yet, the many American people who in polls determined - from the comfort of their homes often cleaned and gardened by immigrants - that Elvira should be arrested and deported if she left the Church where she took refuge to fight for the rights of the millions of families threatened by raids and separation similar to her own, is nothing short of hypocritical. This is particularly apparent when seen in the context of the ongoing illegality of the laws that continue to be passed by the current Congress and Bush administration, both of whom are eroding the US constitution and bill of rights, and facilitating the unprecedented betrayal of the "American way of life." As Elvira noted a few days before her arrest: "If this government would arrest me and separate me from my son, let them do it in front of the men and women who have the responsibility to fix this broken law and uphold the principles of human dignity."

Elvira's brave stance to preserve the sanctity of her own family, and her struggle to ensure that millions of others are not separated from their loved ones by laws that are as unjust as they are inhuman, without a doubt places her in the annals of the great defenders both of human rights and of the values that this society has cherished until today.

Elvira was immediately deported after her arrest, and while her next steps to continue her struggle to reunite herself with her son are as yet unknown, what is certain, is that her steadfast activism on behalf of both the families of immigrants all over the world as well as on behalf of justice and our society's humanity, will one day surely be vindicated.

This is the hope with which this Journal now moves to the Northeast, as, with the present issue, we complete five productive years of work at the University of Illinois at Chicago, to continue the work at the John Jay College of Criminal Justice of the City University of New York. We are grateful to the University of Illinois at Chicago, which, over the past 6 years, has supported our initial development of Latino Studies to its present status as the premier scholarly journal for the dissemination of knowledge on the US Latino population.

Elvira's plight serves as a compelling reminder of the vulnerability of the populations on which we Latino studies scholars normally base our research and writing, a reminder that works as an injunction for us to never forget the 
social dimension of our academic field, irrespective of whether our base of operations is located in the West Coast, the Midwest or the Northeast. May we all remain mindful that the very emergence of Latino studies programs in colleges and universities throughout the nation, happened decades ago as a direct result of community struggles, not unlike that which Elvira has been deported for spearheading.

Saludos!

$$
\begin{array}{r}
\text { Suzanne Oboler } \\
\text { John Jay College of Criminal Justice, } \\
\text { City University of New York. }
\end{array}
$$

Latino Studies (2007) 5, 285-287. doi:10.1057/palgrave.lst.8600269 